\title{
Feeding by the cyclopoid copepod Oithona similis on the microplankton assemblage in the Oyashio region during spring
}

\author{
YUICHIRO NiSHIBE ${ }^{1, *, \dagger}$, TORU KOBARI ${ }^{2} \&$ TAKASHI OTA ${ }^{3}$ \\ ${ }^{1}$ Ocean Research Institute, University of Tokyo, 1-15-1 Minamidai, Nakano, Tokyo 164-8639, Japan \\ ${ }^{2}$ Faculty of Fisheries, Kagoshima University, 4-50-20 Shimoarata, Kagoshima 890-0056, Japan \\ ${ }^{3}$ School of Science and Engineering, Ishinomaki Senshu University, 1 Shinmito, Minamisakai, Ishinomaki 986-8580, Japan
}

Received 9 February 2009; Accepted 27 February 2010

\begin{abstract}
Onboard incubation experiments were conducted to examine the feeding rates and selectivity of the cyclopoid copepod Oithona similis on natural assemblages of microplankton during the spring bloom in the Oyashio region. O. similis cleared ciliates at higher rates $\left(2.8-11.9 \mathrm{~mL}_{\text {copepod }}^{-1} \mathrm{~d}^{-1}\right)$ than dinoflagellates $\left(1.4 \mathrm{~mL}\right.$ copepod $\left.^{-1} \mathrm{~d}^{-1}\right)$, with no detectable ingestion of diatoms. Clearance increased with ciliate size, reaching maximum rates at a size of $\sim 35 \mu \mathrm{m}$ equivalent spherical diameter. The total ingestion rates of protozooplankton (ciliates and dinoflagellates) by $O$. similis ranged between 24.8 and $41.5 \mathrm{ngC}$ copepod ${ }^{-1} \mathrm{~d}^{-1}$, which exceeded by about 2-3 times the metabolic expenditure of the copepod. Applying the ingestion rates to abundance data of $O$. similis, we estimated that the copepod population removed each day $0.1-0.4 \%$ of the protozooplankton standing stock. These results indicate that protozooplankton, especially aloricate ciliates, are an important food resource available to $O$. similis even under bloom conditions in the Oyashio region, though the predation by the copepod did not have a significant impact on protozooplankton assemblages.
\end{abstract}

Key words: ciliates, clearance rate, Oithona similis, selective feeding

The cyclopoid family Oithonidae is often the most abundant group of pelagic copepods in estuarine, coastal and oceanic waters throughout the world (Paffenhöfer 1993, Gallienne \& Robins 2001). Although their numerical importance has been increasingly recognized, our present knowledge on the ecology of oithonid copepods is still rather limited compared to calanoids.

Early laboratory studies using cultured prey have shown that oithonid copepods are omnivorous, ingesting a wide variety of autotrophic and heterotrophic prey items (e.g. Lampitt \& Gamble 1982; Drits \& Semenova 1984; Uchima \& Hirano 1986). Oithonids have also been observed to feed on fecal pellets of other zooplankton (González \& Smetacek 1994), though their coprophagous feeding is still controversial (Reigstad et al. 2005; Iversen \& Poulsen 2007). Recent experimental studies employing natural prey assemblages have revealed that oithonids feed selectively on microzooplanktonic protists, such as ciliates and heterotrophic dinoflagellates (e.g. Nakamura \& Turner 1997; Lonsdale et al. 2000; Castellani et al. 2005a; Atienza et al. 2006). Considering their high abundance, oithonid copepods may serve as an important conduit to trans-

\footnotetext{
* Corresponding author: Yuichiro Nishibe

$\dagger$ Present address: Tohoku National Fisheries Research Institute, 3-27-5 Shinhama-cho, Shigogama 985-0001, Japan; E-mail, ynishibe@affrc.go.jp
}

fer microbial production to higher trophic levels in marine pelagic food webs.

Oithona similis Claus, a small oithonid of $0.7-0.9 \mathrm{~mm}$ body length, dominates the copepod community in terms of abundance throughout the subarctic Pacific (Mackas \& Tsuda 1999), but its trophic ecology and role in this region are not yet well understood. Therefore we examined the feeding rates and selectivity of $O$. similis on natural assemblages of microplankton in the Oyashio region during spring. The emphasis of our study was to assess the importance of protozooplankton (ciliates and dinoflagellates) as a food source for $O$. similis when the diatom bloom occurred, and the predation impact of the copepod population on the protozooplankton assemblage was also estimated.

The present study was conducted at a station $\left(42^{\circ} 00^{\prime} \mathrm{N}\right.$, $145^{\circ} 15^{\prime} \mathrm{E}, 4,000 \mathrm{~m}$ deep) in the Oyashio region, western subarctic Pacific from 16 to 21 April 2007 during a cruise of the $\mathrm{R} / \mathrm{V}$ 'Hakuho-Maru'. During the study period, the station was under diatom bloom conditions (chl. $a$ concentrations: 2.5-5.8 $\mu \mathrm{g} \mathrm{L}^{-1}, \mathrm{~T}$ Kobari, unpubl. data). Experiments were made on three occasions using female specimens sampled on different dates (Table 1). Copepods were collected by slow vertical hauls from $10 \mathrm{~m}$ depth using a ring net $(45 \mathrm{~cm}$ mouth diameter, $50 \mu \mathrm{m}$ mesh size) equipped with a large non-filtering cod-end. Adult females of $O$. similis were immediately sorted out in a 
Table 1. Summary of the feeding experiments. Taxonomic group, size and initial abundance of microplankton prey, and clearance and ingestion rates (mean \pm SD) of female Oithona similis are included. Significant levels for the difference between prey abundances in control and experimental bottles are also shown $(* * * p<0.01, * * p<0.05, * p<0.10$, ns: not significant). ESD: equivalent spherical diameter.

\begin{tabular}{|c|c|c|c|c|c|c|c|}
\hline Expt & Date & $\begin{array}{l}\text { Temp } \\
\left({ }^{\circ} \mathrm{C}\right)\end{array}$ & Prey taxon & $\begin{array}{c}\text { Size } \\
(\mu \mathrm{m} \text { ESD })\end{array}$ & $\begin{array}{l}\text { Initial abundance } \\
\left(\times 10^{3} \text { cells } \mathrm{L}^{-1}\right)\end{array}$ & $\begin{array}{c}\text { Clearance rate } \\
\left(\mathrm{mL} \mathrm{copepod}^{-1} \mathrm{~d}^{-1}\right)\end{array}$ & $\begin{array}{c}\text { Ingestion rate } \\
\left(\text { ngC copepod }^{-1} \mathrm{~d}^{-1}\right)\end{array}$ \\
\hline \multirow[t]{8}{*}{1} & 16-17 April & 5.0 & Diatoms & 27 & 70 & ns & - \\
\hline & 2007 & & Myrionecta rubra & 22 & 7.6 & $3.1 \pm 1.2^{* *}$ & $18.8 \pm 5.7$ \\
\hline & & & Aloricate choreotrichs (small) & 16 & 0.86 & $2.8 \pm 1.3^{* *}$ & $0.91 \pm 0.35$ \\
\hline & & & Aloricate choreotrichs (medium) & 22 & 1.3 & $4.7 \pm 1.7^{* * *}$ & $4.6 \pm 1.1$ \\
\hline & & & Aloricate choreotrichs (large) & 34 & 0.45 & $10.7 \pm 3.8^{* * *}$ & $9.0 \pm 1.3$ \\
\hline & & & Tintinnids & $34^{\mathrm{a}}$ & 0.13 & ns & - \\
\hline & & & Athecate dinoflagellates & 19 & 12 & ns & - \\
\hline & & & Thecate dinoflagellates & 28 & 1.7 & ns & - \\
\hline \multirow[t]{8}{*}{2} & 18-19 April & 5.4 & Diatoms & 26 & 105 & ns & - \\
\hline & 2007 & & Myrionecta rubra & 21 & 2.3 & $6.6 \pm 0.8^{* *}$ & $9.2 \pm 0.7$ \\
\hline & & & Aloricate choreotrichs (small) & 16 & 3.0 & $4.6 \pm 0.6^{* * *}$ & $4.5 \pm 0.4$ \\
\hline & & & Aloricate choreotrichs (medium) & 24 & 1.2 & $5.9 \pm 1.9^{* * *}$ & $7.0 \pm 1.5$ \\
\hline & & & Aloricate choreotrichs (large) & 33 & 0.62 & $8.8 \pm 2.3^{* * *}$ & $11.9 \pm 1.5$ \\
\hline & & & Tintinnids & $30^{\mathrm{a}}$ & 0.25 & $4.2 \pm 2.4^{* *}$ & $0.88 \pm 0.43$ \\
\hline & & & Athecate dinoflagellates & 18 & 13 & $1.4 \pm 0.5^{*}$ & $8.1 \pm 2.7$ \\
\hline & & & Thecate dinoflagellates & 24 & 2.8 & ns & - \\
\hline \multirow[t]{8}{*}{3} & 20-21 April & 5.2 & Diatoms & 27 & 62 & ns & - \\
\hline & 2007 & & Myrionecta rubra & 18 & 1.2 & $3.7 \pm 0.3^{* * *}$ & $3.0 \pm 0.2$ \\
\hline & & & Aloricate choreotrichs (small) & 15 & 2.1 & $3.9 \pm 0.4^{* * *}$ & $3.6 \pm 0.3$ \\
\hline & & & Aloricate choreotrichs (medium) & 23 & 0.76 & $8.0 \pm 1.5^{* * *}$ & $5.4 \pm 0.6$ \\
\hline & & & Aloricate choreotrichs (large) & 37 & 0.32 & $11.9 \pm 4.1^{* * *}$ & $12.1 \pm 1.2$ \\
\hline & & & Tintinnids & $30^{\mathrm{a}}$ & 0.29 & $4.2 \pm 1.4^{* * *}$ & $0.76 \pm 0.19$ \\
\hline & & & Athecate dinoflagellates & 21 & 23 & ns & - \\
\hline & & & Thecate dinoflagellates & 24 & 4.1 & ns & - \\
\hline
\end{tabular}

${ }^{\mathrm{a}}$ Calculated from lorica volume.

constant temperature room $\left(\sim 4^{\circ} \mathrm{C}\right)$ using a dissecting microscope and placed into $500 \mathrm{~mL}$ glass containers filled with seawater. These specimens were maintained overnight in the room. Seawater for experiments was collected from $5 \mathrm{~m}$ depth with $10 \mathrm{~L}$ Niskin-X bottles mounted on a rosette multi sampler and screened through an in-line filter (64 $\mu \mathrm{m}$ mesh). This screening procedure may have altered the composition of natural prey assemblages for the experiments by removing large diatom chains or by damaging some fragile ciliates, but was necessary to remove all metazoans. The screened seawater was mixed gently and poured into six $280 \mathrm{~mL}$ acid-washed polycarbonate bottles. A $200 \mathrm{~mL}$ sample was also taken from the screened seawater and immediately fixed with acid Lugol's solution at a final concentration of $2 \%$ to determine the initial prey abundance. A total of 30-40 female specimens were added to each of three bottles, while the other three bottles without copepods served as controls. The copepod concentrations in the bottles were higher than those in the ambient environment, but were chosen to ensure significant reductions in prey density at high food levels (i.e. under bloom conditions). Incubations were carried out for $24 \mathrm{~h}$ at in situ temperatures in a container on deck with flow-through surface seawater under natural light conditions attenuated to $50 \%$ of incident light using a neutral screen. The temperature was recorded by a temperature logger every $30 \mathrm{~min}$. Except for the ship motion, the bottles in the container were not stirred. At the end of incubation, a $200 \mathrm{~mL}$ aliquot from each bottle was fixed with acid Lugol's solution at a final concentration of $2 \%$ for enumeration of the remaining prey organisms.

The fixed samples were concentrated to $10 \mathrm{~mL}$ by settling in a glass cylinder for at least $24 \mathrm{~h}$. A $0.5-1 \mathrm{~mL}$ aliquot of the sample thus concentrated was transferred to a counting chamber. Microplankton cells $(>10 \mu \mathrm{m})$, including ciliates, dinoflagellates and diatoms, were counted under an inverted microscope at a magnification of $200 \times$. Identification of ciliates was based on Montagnes \& Lynn (1991) and Strüder-Kypke et al. (2001). Identified species and morphotypes were pooled into taxonomic categories and size classes (Table 1). Dinoflagellates were assigned as either athecate or thecate forms, since it is difficult to distinguish autotrophic from heterotrophic cells in samples fixed in Lugol's solution. By using epifluorescence microscopy, however, it was found that the dominant taxa of athecate (Gymnodinium spp. and Gyrodinium spp.) and thecate dinoflagellates (Oxytoxum spp.) during the study period were non-pigmented ( $\mathrm{T}$ Ota, unpubl. data). Cell volume of each prey category was estimated from measurements of linear di- 
mensions made with an image analyzer with CCD camera, by assuming simple geometrical shapes.

Clearance and ingestion rates of $O$. similis were calculated for each prey category according to the equations of Frost (1972) only when the difference in prey concentration between control and experimental bottles proved significant (Student's $t$-test, Table 1). The ingestion rates were converted to carbon on the basis of prey cell volumes using a factor of $0.19 \mathrm{pgC}$ $\mu \mathrm{m}^{-3}$ for ciliates (Putt \& Stoecker 1989) and the equation log $\operatorname{pgC}\left(\right.$ cell $\left.^{-1}\right)=-0.119+0.819 \times \log$ volume $\left(\mu \mathrm{m}^{-3}\right)$ for athecate dinoflagellates (Menden-Deuer \& Lessard 2000).

In all three experiments, the microplankton assemblage was dominated by diatoms (Table 1), mainly consisting of Thalassiosira spp. and Chaetoceros spp. Athecate dinoflagellates were the second most important component of the microplankton, whereas thecate dinoflagellates were less abundant. Ciliates, including Myrionecta rubra (Lohmann), aloricate choreotrichs and tintinnids, accounted for 5-11\% of the total microplankton abundance. Aloricate choreotrichs were separated into three size classes $(<20,20-30$ and $>30 \mu \mathrm{m}$ in maximum cell dimension); dominant genera were Lohmaniella for the small group, Strombidium and Leegaardiella for the medium group, and Strombidium and Strobilidium for the large group.

Oithona similis fed on all size classes of aloricate choreotrichs and $M$. rubra across the three experiments, with clearance rates of 2.8-11.9 and 3.1-6.6 $\mathrm{mL} \mathrm{copepod}^{-1} \mathrm{~d}^{-1}$, respectively (Table 1). Clearance was detected on tintinnids in two out of the three experiments, with a rate of $4.2 \mathrm{~mL}$ cope$\operatorname{pod}^{-1} \mathrm{~d}^{-1}$. Athecate dinoflagellates were ingested on only one occasion, with a relatively low clearance rate of $1.4 \mathrm{~mL}$ cope$\operatorname{pod}^{-1} \mathrm{~d}^{-1}$. No detectable clearance of thecate dinoflagellates and diatoms was measured during any experiment. These results indicate that $O$. similis fed selectively on ciliates over dinoflagellates and diatoms, independent of their relative abundances. Food particle size is an important factor governing prey selection in copepods (Berggreen et al. 1988), but no clear difference was found in cell size, expressed as equivalent spherical diameter (ESD), between the three prey categories examined in the present study (Table 1). Another important factor that potentially influences copepod feeding preference is the motility of prey, especially for ambush feeding copepods such as $O$. similis (Jonsson \& Tiselius 1990; Jakobsen et al. 2005). Svensen \& Kiørboe (2000) demonstrated that $O$. similis detects its prey remotely from the hydromechanical signals generated by the swimming of prey organisms. Hence, highly motile ciliates may be positively selected for by $O$. similis compared to less motile dinoflagellates and immobile diatoms due to their higher detectability by the copepod. Higher clearance rates on ciliates than on dinoflagellates or diatoms have been reported for O. similis (Nakamura \& Turner 1997; Castellani et al. 2005a) and other Oithona spp. (Lonsdale et al. 2000; Atienza et al. 2006), though the opposite trend has also been observed (Atkinson 1995, 1996).

The highest clearance rates on ciliates by $O$. similis measured in each experiment $\left(8.8-11.9 \mathrm{~mL}\right.$ copepod ${ }^{-1} \mathrm{~d}^{-1}$, Table
1) roughly agree with those reported for Oithona spp. (mostly $O$. similis) in subpolar and polar waters, where the thermal conditions $\left(0-8.8^{\circ} \mathrm{C}\right)$ are comparable to the present study ( 3-23.5 mL copepod ${ }^{-1} \mathrm{~d}^{-1}$, Atkinson 1995, 1996, Castellani et al. 2005a), with the exception of the extremely high value of $\sim 75 \mathrm{~mL} \mathrm{copepod}^{-1} \mathrm{~d}^{-1}$ at $0^{\circ} \mathrm{C}$ in Lonsdale et al. (2000). However, it should be noted that our high clearance rates might be underestimates to some extent due to bottle effects (i.e. incubation with a large number of specimens in a small volume), particularly for the large aloricate choreotrichs, whose abundance could have been greatly reduced before the end of incubation (cf. Table 1).

Clearance rates of $O$. similis were clearly related to size of ciliate prey (Fig. 1); the maximum rates were observed for the large aloricate choreotrichs with a size of $\sim 35 \mu \mathrm{m}$ ESD. This suggests that $O$. similis prefers large ciliates, possibly due to their easier detection and ease of capture of larger prey relative to smaller prey items. Nakamura \& Turner (1997) also found such a size-dependent difference in clearance rates for $O$. similis when feeding on aloricate ciliates and dinoflagellates, with the maximum rate at $30-35 \mu \mathrm{m}$ ESD. Tintinnids had a relatively large body size of $30 \mu \mathrm{m}$ ESD, but clearance rates on them were similar to or even lower than those on other smaller taxa (Fig. 1). This rather low clearance rate for tintinnid prey may partly be explained by the presence of a lorica around their cells which is considered to reduce successful capture and ingestion by copepods (Stoecker \& Sanders 1985).

The total ingestion rates of protozooplankton by $O$. similis ranged from 24.8-41.5 $\mathrm{ngC}$ copepod ${ }^{-1} \mathrm{~d}^{-1}$, which is equivalent to $5.1-8.7 \%$ of its body carbon $d^{-1}$ (Table 2). Large aloricate choreotrichs and $M$. rubra together made up more than half of the total carbon ingested (Table 1). Based on the relationship between respiration rate and temperature (Castellani et al. 2005 b), the daily carbon requirement for respiration of $O$. similis was calculated as $12.7 \mathrm{ngC} \mathrm{copepod} \mathrm{d}^{-1} \mathrm{~d}^{-1}$ or $2.6 \%$ of body $\mathrm{C} \mathrm{d}^{-1}$, assuming a respiratory quotient of 0.97 (Ikeda et al. 2000). Thus, the ingestion rates measured here were about $2-3$

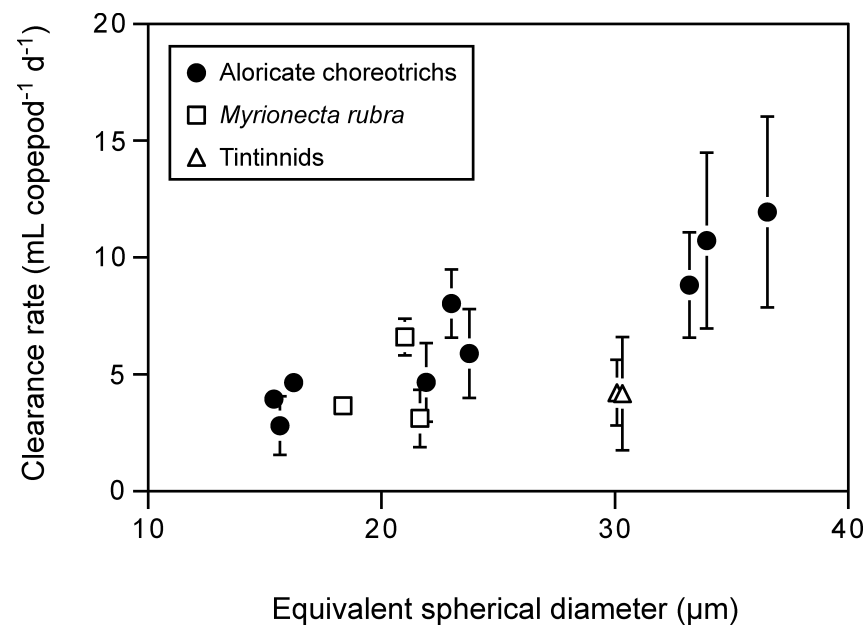

Fig. 1. Clearance rates of female Oithona similis on different taxonomic groups of ciliates, as a function of ciliate size. Error bars, which indicate $\pm \mathrm{SD}$, are shown when they exceed the size of a symbol. 
Table 2. Carbon weight, total ingestion rate on protozooplankton and daily ration of female Oithona similis. Values are mean \pm SD

\begin{tabular}{cccc}
\hline Expt & $\begin{array}{c}\text { Carbon } \\
\text { weight } \\
(\mathrm{ngC})^{\mathrm{a}}\end{array}$ & $\begin{array}{c}\text { Total ingestion rate of } \\
\text { protozooplankton } \\
\left(\mathrm{ngC} \mathrm{copepod} \mathrm{d}^{-1}\right)\end{array}$ & $\begin{array}{c}\text { Daily ration } \\
\left(\% \text { body } \mathrm{C} \mathrm{d}^{-1}\right)\end{array}$ \\
\hline 1 & $488 \pm 55$ & $33.3 \pm 6.9$ & $6.8 \pm 1.4$ \\
2 & $480 \pm 55$ & $41.5 \pm 2.8$ & $8.7 \pm 0.6$ \\
3 & $485 \pm 83$ & $24.8 \pm 1.7$ & $5.1 \pm 0.3$ \\
\hline
\end{tabular}

${ }^{\text {a }}$ Estimated from prosome length measured for formalin-preserved individuals $(n=30)$ using the length-weight regression from Sabatini \& Kiørboe (1994).

times higher than the metabolic expenditure of $O$. similis. This indicates that protozooplankton, especially aloricate ciliates, are an important food source for $O$. similis even during the spring diatom bloom, though the contribution of other potential foods including phytoflagellates (Castellani et al. 2005a), copepod nauplii (Nakamura \& Turner 1997) and fecal pellets (González \& Smetacek 1994) was not assessed in our experiments.

To determine the abundance of $O$. similis, a ring net $(36 \mathrm{~cm}$ mouth diameter, $63 \mu \mathrm{m}$ mesh size) equipped with a flow meter (Rigosha) was hauled vertically at a speed of $0.5 \mathrm{~m} \mathrm{~s}^{-1}$ from $150 \mathrm{~m}$ depth on 16, 18 and 20 April. Samples were preserved immediately on board in a $2 \%$ formaldehyde-seawater solution buffered with borax. Adults and copepodites of $O$. similis were enumerated under a stereomicroscope. Abundance of the $O$. similis population (adults and copepodites) ranged between 1,410 and 2,360 indiv. $\mathrm{m}^{-3}$ during the study period. Assuming that the weight-specific ingestion rate of $O$. similis was independent among the developmental stages of the copepod (cf. Table 2), the population ingestion rates were estimated as $23.4-55.8 \mu \mathrm{gC} \mathrm{m}^{-3} \mathrm{~d}^{-1}$, which equates to $0.3-1.5 \%$ and $0.1-0.4 \%$ of the ciliate $\left(3.8-9.8 \mu \mathrm{gC} \mathrm{L}^{-1}, \mathrm{~T}\right.$. Ota, unpubl. data) and total protozooplankton biomass $\left(14.0-35.6 \mu \mathrm{gC} \mathrm{L}^{-1}\right)$ in the surface water, respectively. Thus, the predation impact on the protozooplankton assemblage by $O$. similis appeared to be low in the Oyashio region during spring. However, considering that the abundance of $O$. similis reaches as high as $\sim 20,000$ indiv. $\mathrm{m}^{-3}$ in mid summer (Y Nishibe, unpubl. data), the copepod may seasonally be important as a consumer of protozooplankton and as an intermediary in the transfer of microbial production to higher trophic levels in this region.

\section{Acknowledgements}

This study is a part of the research program Ocean Ecodynamics Comparison of Subarctic Pacific (OECOS). We thank the participants of OECOS-WEST cruise and the captain and crews of R/V 'Hakuho-Maru' for their help in field sampling. $\mathrm{YN}$ is grateful to Dr. A Tsuda for providing laboratory facilities for microscopic analysis. This research was partly supported by a Grant-in-Aid for JSPS Fellows to YN (No.
$19 \cdot 4747)$ from the Japanese Society for the Promotion of Science.

\section{References}

Atienza D, Calbet A, Saiz E, Alcaraz M, Trepat I (2006) Trophic impact, metabolism, and biogeochemical role of the marine cladoceran Penilia avirostris and the co-dominant copepod Oithona nana in NW Mediterranean coastal waters. Mar Biol 150: 221-235.

Atkinson A (1995) Omnivory and feeding selectivity in five copepod species during spring in the Bellingshausen Sea, Antarctica. ICES J Mar Sci 52: 385-396.

Atkinson A (1996) Subantarctic copepods in an oceanic, low chlorophyll environment: ciliate predation, food selectivity and impact on prey populations. Mar Ecol Prog Ser 130: 85-96.

Berggreen U, Hansen B, Kiørboe T (1988) Food size spectra, ingestion and growth of the copepod Acartia tonsa during development: implications for determination of copepod production. Mar Biol 99: 341-352.

Castellani C, Irigoien X, Harris RP, Lampitt RS (2005a) Feeding and egg production of Oithona similis in the North Atlantic. Mar Ecol Prog Ser 288: 173-182.

Castellani C, Robinson C, Smith T, Lampitt RS (2005b) Temperature affects respiration rate of Oithona similis. Mar Ecol Prog Ser 285: 129-135.

Drits AV, Semenova TN (1984) Experimental investigations of the feeding of Oithona similis Claus. Oceanology 24: 755-759.

Frost BW (1972) Effects of size and concentration of food particles on the feeding behavior of the marine planktonic copepod Calanus pacificus. Limnol Oceanogr 17: 805-815.

Gallienne CP, Robins DB (2001) Is Oithona the most important copepod in the world's oceans? J Plankton Res 23: 1421-1432.

González HE, Smetacek V (1994) The possible role of the cyclopoid copepod Oithona in retarding vertical flux of zooplankton faecal material. Mar Ecol Prog Ser 113: 233-246.

Ikeda T, Torres JJ, Hernández-León S, Geiger SP (2000) Metabolism. In: ICES Zooplankton Methodology Manual (eds Harris RP, Wiebe PH, Lenz J, Skjoldal HR, Huntley M). Academic Press, San Diego, pp 455-532.

Iversen MH, Poulsen LK (2007) Coprohexy, coprophagy, and coprochaly in the copepods Calanus helgolandicus, Pseudocalanus elongatus, and Oithona similis. Mar Ecol Prog Ser 350: 79-89.

Jakobsen HH, Halvorsen E, Hansen BW, Visser AW (2005) Effects of prey motility and concentration on feeding in Acartia tonsa and Temora longicornis: the importance of feeding modes. J Plankton Res 27: 775-785.

Jonsson PR, Tiselius P (1990) Feeding behaviour, prey detection and capture efficiency of the copepod Acartia tonsa feeding on planktonic ciliates. Mar Ecol Prog Ser 60: 35-44.

Lampitt RS, Gamble JC (1982) Diet and respiration of the small planktonic marine copepod Oithona nana. Mar Biol 66: 185-190.

Lonsdale DL, Caron DA, Dennett MR, Schaffner R (2000) Predation by Oithona spp. on protozooplankton in the Ross Sea, Antarctica. DeepSea Res II 47: 3273-3283.

Mackas DL, Tsuda A (1999) Mesozooplankton in the eastern and western subarctic Pacific: community structure, seasonal life histories, and interannual variability. Prog Oceanogr 43: 335-363.

Menden-Deuer S, Lessard EJ (2000) Carbon to volume relationships for dinoflagellates, diatoms, and other protist plankton. Limnol Oceanogr 45: 569-579.

Montagnes DJS, Lynn DH (1991) Taxonomy of choreotrichs, the major marine planktonic ciliates, with emphasis on the aloricate forms. Mar Microb Food Webs 5: 59-74.

Nakamura Y, Turner JT (1997) Predation and respiration by the small cy- 
clopoid copepod Oithona similis: How important is feeding on ciliates and heterotrophic flagellates? J Plankton Res 19: 1275-1288.

Paffenhöfer GA (1993) On the ecology of marine cyclopoid copepods (Crustacea, Copepoda). J Plankton Res 15: 37-55.

Putt M, Stoecker DK (1989) An experimentally determined carbon:volume ratio for marine "oligotrichous" ciliates from estuarine and coastal waters. Limnol Oceanogr 34: 1097-1103.

Reigstad M, Wexels Riser C, Svensen C (2005) Fate of copepod faecal pellets and the role of Oithona spp. Mar Ecol Prog Ser 304: 265-270.

Sabatini M, Kiørboe T (1994) Egg production, growth and development of the cyclopoid copepod Oithona similis. J Plankton Res 16: 1329-1351.
Stoecker DK, Sanders NK (1985) Differential grazing by Acartia tonsa on a dinoflagellate and a tintinnid. J Plankton Res 7: 85-100.

Strüder-Kypke MC, Kypke ER, Agatha S, Warwick J, Montagnes DJS (2001) The user-friendly guide to coastal planktonic ciliates. Available at: www.liv.ac.uk/ciliate.

Svensen C, Kiørboe T (2000) Remote prey detection in Oithona similis: hydromechanical versus chemical cues. J Plankton Res 22: 1155-1166

Uchima M, Hirano R (1986) Food of Oithona davisae (Copepoda: Cyclopoida) and the effect of food concentration at first feeding on the larval growth. Bull Plankton Soc Japan 33: 21-28. 